\title{
POSSIBLE LITTLE BLUE HERON SIGHTING
}

WILLIAM ROBERTSON, 712 11th Street East, Saskatoon, SK S7N 0G5

On Friday, 24 July 1998, I was making a quick trip out to St. Peter's Abbey from Saskatoon and saw a curious sight. Just a few kilometres west of Humboldt on Highway 5 , at approximately 5:15 p.m., I saw what looked to be a miniature Great Blue Heron (Ardea herodius) in a water-filled ditch on my right-hand side. It was close enough in detail to what I know to be the Great Blue that I even remarked to my 14-year-old son, "Look, there's a Great Blue Heron." As I drove on, I became troubled by its size and thought it sure wasn't very "Great." It also did not have the white cap which one can sometimes see on the Great Blue, though it certainly was a slaty blue in colour. But I was busy and drove on.

A week later, after seeing numerous hawks in the Cypress Hills area, I sat down with my Peterson's Field Guide to Western Birds and stumbled across herons. There was the Little Blue( Egretta caerulea) matching what I saw, particularly with regard to size. When I looked at the "Where found" section and saw E. U.S. south to Peru I was prepared to revise my notion of what l'd seen, until I read the "casual straggler" part that listed numerous southwestern U.S. states and Saskatchewan. Now I was prepared to believe that I may have seen a Little Blue Heron.

The fact that a flower is showy does not guarantee that it will attract butterflies.

Peonies, gladiolus, nearly all roses, and most fancy double blossoms are all but useless for the purpose. A homely dandelion is worth any number of expensive roses in the butterfly garden.

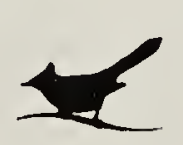

The Ruby-Throated Hummingbird flies approximately 25 feet above land or water at speeds of $30-40 \mathrm{mph}$ while migrating. 